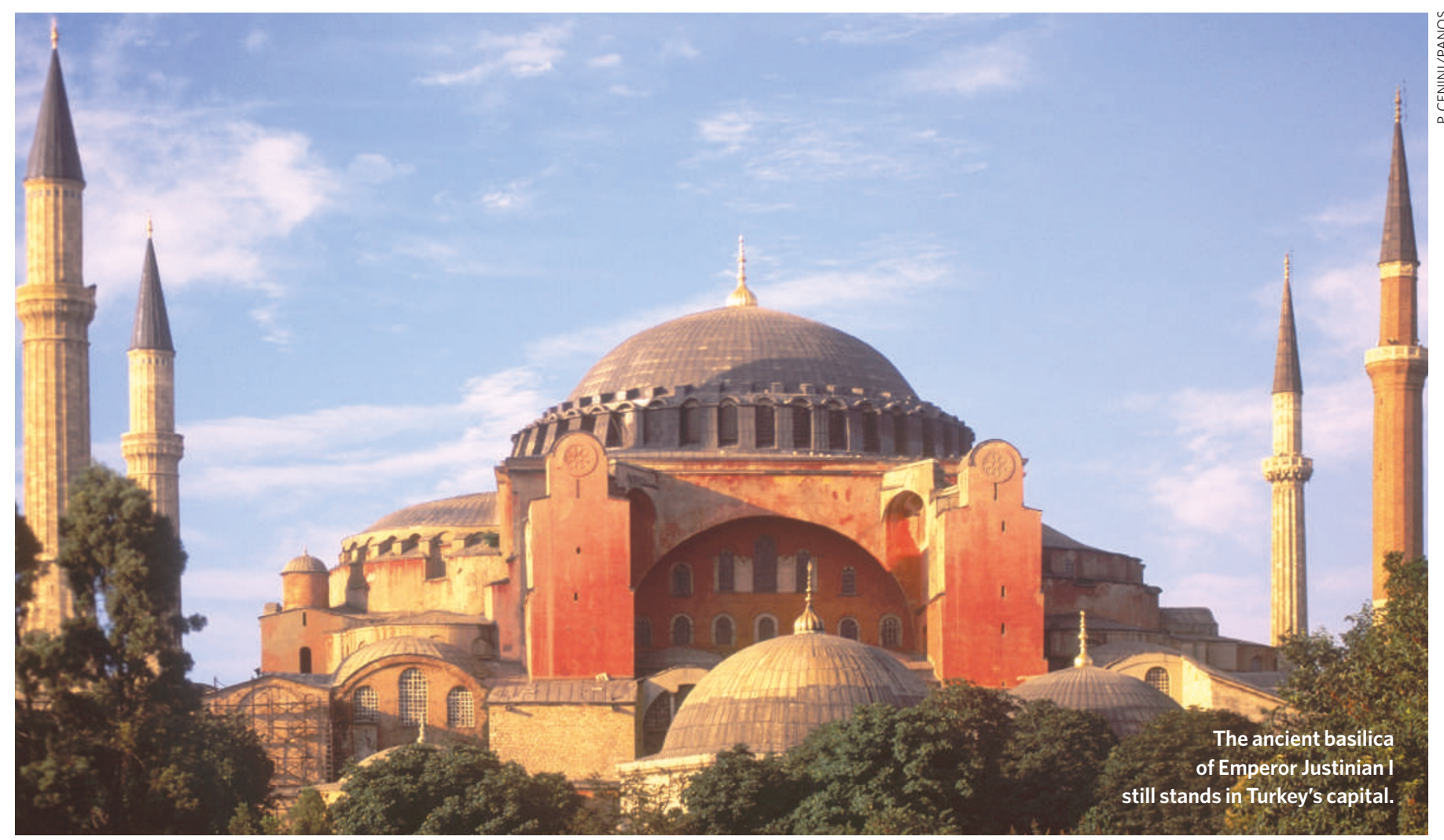

\title{
Shaken, not stirred
}

\section{Hagia Sophia has stood four-square in Istanbul for more than 1,500 years. Virginia Hughes finds out how this venerable building has resisted the area's numerous earthquakes.}

stanbul is a city in motion. In just the past four decades, its population has exploded from 2 million to 10 million people, with

migrants flowing in from the countryside for work. Most of them now live in multi-storey concrete structures, thrown up in haste and without concern for earthquake resistance.

That's a problem, because Istanbul is also literally in motion - perched as it is near the North Anatolian fault (see map). In 1999, a magnitude7.4 earthquake killed some 18,000 people and destroyed more than 15,000 buildings in and around Izmit, a town lying 100 kilometres to the east ${ }^{1}$. If such an earthquake were to strike the capital - and that's worryingly likely — twice as many might die, suggests a recent analysis led by Mustafa Erdik, an earthquake engineer at Boğaziçi University in Istanbul ${ }^{2}$. And some 40,000 buildings could be destroyed.

Yet one of Istanbul's most famous buildings has already survived 15 centuries of earthquakes. It is a 55-metre-high, brick-andmortar domed construction - Hagia Sophia. For decades, historians have debated how the building has withstood such seismic stress, and whether its architects planned it that way. Now, computer models and chemical analyses are providing clues to fuel these long-running debates. Were the Byzantine builders inventing new technologies, or just lucky? And when
Istanbul is hit by the next big one, will Hagia Sophia collapse - or be the only thing left standing in the rubble?

\section{Being flexible}

Hagia Sophia has endured in a land notorious for geophysical, political and religious instability. When the Muslim Ottomans invaded in 1453, they transformed it from a Christian basilica into a mosque; in 1935, the Turkish government secularized it by turning it into a museum.

The original building got its start in AD 532, at the command of Emperor Justinian I. Meaning 'holy wisdom' in Greek, Hagia Sophia was the first structure to combine the rectangular plan of traditional basilicas with the central dome of imperial buildings such as the Pantheon in Rome. Justinian spared no expense; the church cost $145,000 \mathrm{~kg}$ of gold (worth US $\$ 3$ billion today) and is one of the most expensive structures ever built.

And who better to build what was then the greatest church in the world than the two greatest experts of the time: Anthemius of Tralles and Isidorus of Miletus. "Anthemius was the best military engineer that Justinian had," says Ahmet Çakmak, a professor emeritus in earthquake engineering at Princeton University. "Isidorus was the director of the biggest scientific academy in the world," he adds. "It's like you hired Oppenheimer to build your house."

Çakmak, who spent his childhood visiting Hagia Sophia, has always been fascinated by earthquakes. At 23, he left Turkey to teach at Princeton in New Jersey, and by the time Istanbul hit its population boom a decade later, he was chair of the engineering department. But it wasn't until the mid-1980s that the theoretically minded Çakmak turned his attention to practical studies of the monument from his childhood.

At the time, his engineering colleague Robert Mark was creating computerized models to show how buildings bear their loads. Mark's work explained how medieval builders' observations of mortar cracks probably led to the invention of flying buttresses ${ }^{3}$, for example. Çakmak encouraged him to make the same kind of studies of Hagia Sophia. "The technology was just beginning," Mark recalls.

Together, they made computer models that could simulate how the church moved under various conditions, such as earthquakes. They have been arguing over the results ever since.

Today's Hagia Sophia is a hodgepodge of domes, buttresses, supporting walls and minarets, added at various times in the name of religion or restoration. But, as the computer models show, the church's structural strength 
comes from its original square core.

"Virtually all domed structures before this time were essentially domes on cylinders," says architectural historian Rabun Taylor of Harvard University in Cambridge, Massachusetts. In contrast, Hagia Sophia is built on the crowns of arches, which support the dome and then extend to piers that form the corners of a square. "That was new," says Taylor.

Also new were Hagia Sophia’s pendentives - the concave triangular sections of brick and mortar that made smooth structural transitions between the curved tops of the four arches and the bottom of the dome.

But how did Anthemius and Isidorus plan their structure, before the discovery of calculus or Newton's force laws? Although engineers and historians disagree about the extent of their knowledge and innovation, most agree that the architects must have relied heavily on simple geometric ratios, and on the example of existing buildings such as the Pantheon.

\section{Cracking idea}

Until Mark modelled the Pantheon's dome in the late 1980s, most historians believed the windows in Hagia Sophia's dome were added solely for visual effect. There are 40 of these windows, one between each of the ribs of brick and mortar that support the 31-metrediameter dome. Mark's research suggested that the windows were added to avoid cracking ${ }^{4}$. "They knew from looking at the Pantheon that that region would want to crack anyway along the axis of the windows," he explains, "so they used windows to, in a way, put the cracks in themselves."

That would have helped in seismically active Constantinople, as the city was then known. Hagia Sophia has stood, sustaining only partial damage, through more than a dozen major earthquakes. Part of this success can be attributed to its arches and pendentives, which when shaken distribute the dome's weight equally among the four underlying pillars. But

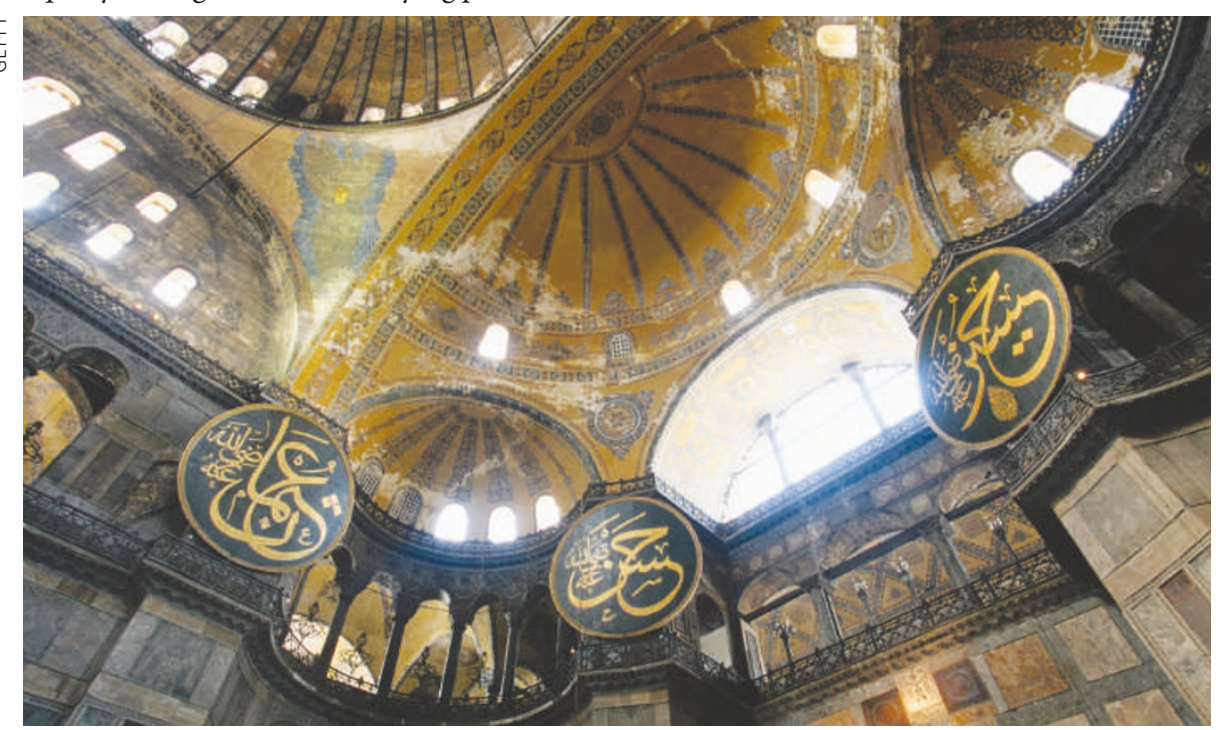

Ancient innovation: triangular 'pendentives' join supporting arches to the building's enormous dome.

the very bricks and mortar that make up the church have also helped.

Modern earthquake-resistant buildings are constructed to be light and flexible, in order to withstand shaking. Hagia Sophia was both, far ahead of its time. Its bricks are much lighter and more porous than the bricks used elsewhere in the empire in that period. Çakmak's studies have shown that the bricks must have been baked at relatively low temperatures, less than about $750{ }^{\circ} \mathrm{C}$, to get the right reaction between sand and lime 5 . "If it becomes higher than that," he says, "the sand becomes glassy and dense."

The original builders also used a special kind of mortar. Working with his colleagues at the National Technical University of Athens, Greece, Çakmak has found that the mortar contains a calcium-silicon compound similar to that used in today's Portland cement ${ }^{6}$. The high tensile strength of this mixture has allowed the church to absorb the shaking from large earthquakes, he says. In 2002, the team reported that, amazingly, after 1,500 years the calcium and silicon in the mortar could still react". "The mortar cures itself," he explains. "After each shaking, there are microcracks, which are healed over time." (Mark, for his part, argues that the mortar's consistency may vary throughout the building, and thus cannot explain everything.)

The ratio of brick to mortar used in the build-

ing may also contribute to its strength. To build faster, the masons used extremely thick mortar joints, often thicker than the bricks themselves. The thick joints make the material "more like reinforced concrete", says Çakmak - although the technique is only possible with such a strong mortar.

Did the builders include such earthquake-resistant features intentionally? Before Hagia Sophia, says Çakmak, architects simply created very heavy buildings if they wanted them to survive

earthquakes. But Anthemius was interested in the topic and even, reportedly, built his own earthquake-simulation machine. "He realized that the forces in a dynamic system are proportional to mass," argues Çakmak. "So his concept of using lighter brick and flexible mortar instead of stone makes good sense."

But Mark disagrees with his friend, coming down on the side of most architectural historians. "Ahmet thinks that they had knowledge that I don't think they had," he says.

\section{Old reliable}

Such queries aside, many wonder how Hagia Sophia will fare in the next great earthquake - the region just south of Istanbul is expected to experience two tremors of equal or greater magnitude to the Izmit earthquake in the next few decades 8 . In 1991, a team of Turkish and US researchers fitted Hagia Sofia with several vibration sensors. From data gathered during tiny earthquakes, Çakmak created three-dimensional computer simulations that could predict how the building might move during a large earthquake ${ }^{9}$. The model shows that when hit by a magnitude- 7.5 tremor, the walls of Hagia Sophia will tremble and sway dramatically back and forth. The tops of its arches will feel the most stress. But the dome will remain unscathed, and the church will stand.

And if the earthquake is greater than magnitude 7.5? "If it's greater than that, there's very little we can do," Çakmak says. Indeed, if the worst earthquake predictions come true, Hagia Sophia - standing or not - will be the last thing anybody is worried about.

Virginia Hughes is a science writer in New York City.

\footnotetext{
. Parsons, T. et al. Science 288, 661-665 (2000).

2. Erdik, M. \& Durukal, E. Nat. Hazards (in the press)

3. Bork, R., Mark, R. \& Murray, S. J. Soc. Arch. Hist. 56, 478-493 (1997).

4. Mark, R. Am. Sci. March/April 142-150 (1987)

5. Moropoulou, A., Çakmak, A. \& Polikreti, K. J. Am. Ceram. Soc. 85, 366-372 (2002).

6. Moropoulou, A. et al. in Wessex Inst. Trans. Built Environ. 15, (eds Brebbia, C. A., Hernandez, S. \& El-Sayed, M.) (WIT Press, 1995).

7. Moropoulou, A., C.akmak, A. S., Biscontin, G., Bakolas, A. \& Zendri, E. Constr. Bldg Mater. 16, 543-552 (2002).

8. Hubert-Ferrari, A. et al. Nature 404, 269-273 (2000)

9. C.akmak, A., Moropoulou, A. \& Mullen, C. L. Soil Dynam. Earthquake Eng. 14, 125-133 (1995)
} 